\title{
HUBUNGAN PEMENUHAN KEBUTUHAN SPIRITUAL DENGAN TINGKAT KECEMASAN PADA PASIEN KANKER DI RSU KABUPATEN TANGERANG
}

\author{
Ratumas Ratih Puspita, Siti Mahmudah \\ Program Studi Pendidikan Ners, STIKes Widya Dharma Husada Tangerang \\ Jl. Pajajaran No 1, Pamulang Barat, Tangerang Selatan, Banten,15417 \\ E-mail: ratumasratihpuspita@wdh.ac.id
}

\begin{abstract}
ABSTRAK
Kanker berasal dari satu sel gen yang mengalami kerusakan. Penderita kanker akan mengalami masalah tekanan psikologis salah satunya adalah kecemasan. Pemenuhan kebutuhan spiritual di berikan kepada pasien kanker guna untuk kurangi cemas. Tujuan penelitian: Untuk mengetahui hubungan pemenuhan kebutuhan spiritual dengan tingkat kecemasan pada pasien kanker di RSU Kabupaten Tangerang. Metode: Desain penelitian menggunakan deskriptif analitik dengan pendekatan kuantitatif dan rancangan cross senctional. Sampel penelitian adalah pasien kanker di ruang Soka RSU Kabupaten Tangerang sebanyak 31 responden menggunakan metode Non Probability Sampling dengan teknik Purposive sampling. Penelitian dilakukan pada tanggal 7 sampai 12 Juni 2017 di RSU Kabupaten Tangerang. Hasil: Hasil penelitian diperoleh kebutuhan spiritual yang terpenuhi 21 orang $(67,7 \%)$, dan yang tidak terpenuhi 10 orang $(32,3 \%)$. Tingkat kecemasan ringan 20 orang (64,5\%), kecemasan sedang 11 orang (35,5\%). Hasil uji statistik diperoleh nilai $\mathrm{r}-0,209(p>0,05)$. Kesimpulan: dengan demikian dapat disimpulkan bahwa $\mathrm{H}_{0}$ diterima artinya tidak ada hubungan antara pemenuhan kebutuhan spiritual dengan tingkat kecemasan pada pasien kanker di RSU Kabupaten Tangerang. Saran: Walaupun tidak ada hubungan antara pemenuhan kebutuhan spiritual dengan tingkat kecemasan pada pasien kanker di harapkan sebagai tenaga medis dapat lebih memperhatikan kebutuhan spiritual pasien guna untuk memenuhi pemenuhan kebutuhan spiritual pasien.
\end{abstract}

Kata kunci: kanker, pemenuhan kebutuhan spiritual, tingkat kecemasan

\begin{abstract}
Cancer comes from a single gene cell that is damaged. Fulfillment of spiritual needs in giving to cancer patients to to reduce anxiety. The aim of this research: To know the relation of the fulfillment of spiritual needs with the level of anxiety in cancer patients in RSU Tangerang District. Methods: The research design uses descriptive analytic with quantitative approach and cross senctional design. The sample of the research was cancer patient in Soka RSU of Tangerang Regency as many as 31 respondents using Non Probability Sampling method with Purposive sampling technique. The study was conducted on 7 to 12 June 2017 at Tangerang District General Hospital. Results: From the research result obtained spiritual requirement that fulfilled 21 person (67,7\%) not fulfilled 10 person (32,3\%). Mild anxiety level 20 person $(64.5 \%)$, moderate anxiety 11 person $(35.5 \%)$. Statistical test results obtained $r-0,209$ ( $p>0,05)$. Conclusion: Thus it can be concluded that $H_{0}$ accepted means there is no relationship between the fulfillment of spiritual needs with anxiety levels in cancer patients in RSU Tangerang District. Suggestion: Although there is no relationship between the fulfillment of spiritual needs with anxiety levels in cancer patients is expected as medical personnel can pay more attention to the spiritual needs of patients in order to meet the fulfillment of the spiritual needs of patients.
\end{abstract}

Keywords : cancer, the fulfillment of spiritual needs, anxiety levels.

\section{LATAR BELAKANG}

Kanker berasal dari satu sel gen yang mengalami kerusakan. Sel gen yang rusak bisa menjadi liar dan berkembang tanpa henti sehingga dari satu sel menjadi jutaan sel dan membentuk jaringan baru jaringan inilah yang disebut tumor atau kanker
(Subagja, 2014). Jumlah penderita kanker dan kematikan akibat kanker terus mengalami peningkatan dari tahun ke tahun baik di dunia maupun di indonesia.

Menurut WHO, organisasi kesehatan dunia, pada tahun 2012 diperkirakan terdapat 14 juta kasus 
kanker baru, dan sekitar 8,2 juta diantara dinyatakan meninggal dunia akibat kanker. Pada tahun 2017 ini diprediksikan hampir 9 juta orang meninggal di seluruh dunia akibat kanker dan akan terus meningkat hingga 13 juta orang per tahun di 2030 (depkes, 2017). Di Indonesia, prevalensi penyakit kanker juga cukup tinggi yaitu 1,4 per 100 penduduk atau sekitar 347.000 orang (Riskesdas, 2013).

Di salah satu rumah sakit pemerintah di daerah Kabupaten Tangerang, pada bulan Januari - April 2017 terdapat kasus 202 pasien kanker yang menjalani baik perawatan maupun pengobatan di RSU Kabupaten Tangerang dengan berbagai macam kanker dan stadiumnya (RSU Kabupaten Tangerang, 2017).

Penyakit kanker berdampak terhadap seluruh aspek kehidupan penderita, baik fisik, psikologis maupun spiritual (Ahn dkk, 2009 dalam Nuraeni dkk, 2015). Secara fisik penderita akan mengalami nyeri, fatigue, serta penurunan fungsi fisik dan kelelahan yang dirasakan terus menerus, kondisi ini akan mengakibatkan timbulnya masalah psikologis pada pasien (Grimsbø dkk, 2012 dalam Nuraeni dkk, 2015).

Tekanan psikologis yang sering kali muncul adalah kecemasan, insomnia, sulit berkonsentrasi, tidak nafsu makan, dan merasa putus asa yang berlebihan, hingga hilangnya semangat hidup (Nurpeni, 2013). Dari sekian tekanan psokologis yang sering kali muncul tersebut, satu tekanan psikologis yang akan dibahas disini adalah kecemasan. Di antaranya kecemasan dapat terjadi karna efek, seperti proses pengobatan, ekonomi, efek pengobatan, bahkan tidak jarang kematian menjadi sumber kecemasan (Yusuf, 2007 dalam Rahmah, 2016).

Kecemasan merupakan bagian dari kehidupan manusia yang ditandai dengan perasaan ketakutan atau kekhawatiran yang mendalam dan berkelanjutan (Nadeak, 2010 dalam Utami 2013). Kecemasan akan meningkat ketika individu membayangkan terjadinya perubahan dalam hidupnya di masa depan akibat penyakit atau akibat dari proses penanganan suatu penyakit, serta mengalami kekurangan informasi mengenai sifat suatu penyakit dan penanganannya (Lubis dan Hasimi, 2009).

Pada pasien kanker tingkat kecemasan cenderung lebih tinggi dari stress dan depresi. Menurut Smeltzer et al. (2010) bahwa salah satu cara untuk mengurangi kecemasan pasien yakni dengan dukungan spiritual yang sesuai dengan kebutuhan dan keyakinan pasien (Ariyani dkk, 2014).

Pasien merasakan pentingnya pemenuhan kebutuhan spiritual (Nuraeni dkk, 2015). Pada pasien kanker, terutama kanker stadium lanjut, upaya penyembuhan menjadi sangat sulit, sedikit sekali pasien yang dapat kembali pulih dari penyakitnya (Nuraeni dkk, 2015). Menurut Murray (2004), spiritual care pada pasien dengan penyakit terminal dirasakan oleh pasien sebagai hal yang penting (Nuraeni dkk, 2015).

Pasien membutuhkan intervensi spiritual dengan porsi yang cukup besar, selain pengobatan ataupun perawatan fisik (Mcgrath, 2004 dalam Nuraeni dkk, 2015). Pasien yang memiliki kebutuhan spiritual mereka ditangani dengan menerima perawatan spiritual guna untuk kurangi cemas, kurangi stress, meningkatkan koping, dan memiliki prognosis yang lebih baik dari penyakit (Abuatiq, 2015).

Pentingnya

pemenuhan kebutuhan spiritual juga diperkuat oleh Puchalski (2009) yang menyatakan bahwa tidak semua penyakit dapat disembuhkan namun selalu ada ruang 
untuk "healing"atau penyembuhan (Nuraeni dkk, 2015). Pemenuhan kebutuhan spiritual pada pasien tidak hanya bermanfaat bagi pasien saja tetapi dapat berdampak terhadap profesionalisme kerja perawat (Kociszewski, 2004 dalam Nuraeni dkk, 2015) dan pelayanan kesehatan lainnya.

\section{METODE}

Desain penelitian menggunakan deskriptif analitik dengan pendekatan kuantitatif dan rancangan cross senctional. Penelitian dilakukan pada tanggal 7 sampai 12 Juni 2017 di RSU Kabupaten Tangerang. Populasi dalam penelitian ini adalah pasien kanker yang menjalani pengobatan kemoterapi sebanyak 31 responden. pengambilan sample penelitian ini menggunakan metode Non Probability Sampling yaitu sampling non probalitas (non random).

Proses pengumpulan data menggunakan 2 jenis kuesioner yaitu kuesioner pemenuhan kebutuhan spiritual Kuesioner pemenuhan kebutuhan spiritual yang diberikan tenaga medis kepada pasien kanker dan kuesioner tingkat kecemasan pada pasien kanker.

Analisa Data

Analisis univariat pada penelitian ini digunakan untuk mengetahui distribusi frekuensi pada karakteristik responden (usia, jenis kelamin, tingkat pendidikan, agama, pekerjaan, jenis kanker, stadium kanker, pengobatan kanker, riwayat pengobatan kanker, siklus kemoterapi, pemenuhaan kebutuhan spiritual yang diberikan tenaga medis pada pasien kanker, tingkat kecemasan pada pasien kanker), variabel independent (pemenuhan kebutuhan spiritual) dan variabel dependent (tingkaat kecemasan pada pasien kanker).

Analisa bivariat digunakan uji statistic uji spearman rho dengan tingkat kepercayaan $95 \%(\alpha=0,05)$, dari penelitian yang dilakukan Pvalue $>\alpha$ maka hasil perhitungan statistic bermakna artinya $\mathrm{H}_{0}$ diterima dan $\mathrm{H}_{\mathrm{a}}$ ditolak artinya tidak ada hubungan antara variabel independen dan variabel dependen.

\section{HASIL PENELITIAN}

Berdasarkan Tabel 1 menunjukkan bahwa rata-rata usia responden adalah 45,94 dengan standar deviasi 10,671. Dari hasil estimasi interval $95 \%$ diperoleh 42,02-49,85 sehingga disimpulkan sebesar $95 \%$ diyakini bahwa rata-rata pekerja berusia 42,02 sampai 49,85 tahun, dimana usia termuda 17 tahun dan usia tertua 64 tahun.

\section{Karakteristik Responden}

Tabel 1

Karakteritis Responden Berdasarkan Data Demografi Usia

\begin{tabular}{cccccc}
\hline Karakteristik & Kategori & N (\%) & Mean (SD) & Min-Max & 95\%CI \\
\hline Usia & & $31(100 \%)$ & $45,94(10,671)$ & $17-64$ & $42,02-49,85$ \\
\hline
\end{tabular}

Tabel 2

Karakteristik Responden Berdasarkan Data Demografi $(n=31)$.

\begin{tabular}{clll}
\hline Karakteristik & Kategori & N & Presentasi (\%) \\
\hline \multirow{2}{*}{ Jenis kelamin } & Laki-laki & 8 & 25,8 \\
\cline { 2 - 4 } & Perempuan & 23 & 74,2 \\
\hline \multirow{2}{*}{ Pendidikan } & Tidak sekolah & 2 & 6,5 \\
\cline { 2 - 4 } & SD & 13 & 41,9 \\
\hline
\end{tabular}




\begin{tabular}{llll}
\hline \multirow{5}{*}{ Agama } & SMP & 6 & 19,4 \\
\cline { 2 - 4 } & SMA & 9 & 29,0 \\
\cline { 2 - 4 } & Diplomat/Sarjana & 1 & 3,2 \\
\hline \multirow{3}{*}{ Pekerjaan } & Islam & 29 & 93,5 \\
\cline { 2 - 4 } & Budha & 2 & 6,5 \\
\hline & PNS & 1 & 3,2 \\
\cline { 2 - 4 } & Swasta & 3 & 9,7 \\
\cline { 2 - 4 } & Wiraswasta & 3 & 9,7 \\
\cline { 2 - 4 } & Buruh & 2 & 6,5 \\
\cline { 2 - 4 } & IRT & 21 & 67,7 \\
\cline { 2 - 4 } & Pelajar & 1 & 3,2 \\
\hline
\end{tabular}

Tabel 2 menunjukkan bahwa responden dengan jenis kelamin lakilaki berjumlah 8 orang $(25,8 \%)$, perempuan berjumlah 23 orang (74,2\%); responden dengan pendidikan SD berjumlah 13 orang (41,9\%), pasien kanker dengan pendidikan SMP berjumlah 6 orang $(19,4 \%)$, pasien kanker dengan pendidikan SMA berjumlah 9 orang $(29,0 \%)$, pasien kanker dengan pendidikan Diplomat/Sarjana berjumlah 1 orang $(3,2 \%)$, pasien kanker yang tidak sekolah berjumlah 2 orang $(6,5 \%)$.

Tabel 2 menunjukkan bahwa responden yang beragama Islam berjumlah 29 orang $(93,5 \%)$, pasien kanker yang beragama Budha berjumlah 2 orang $(6,5 \%)$; responden dengan pekerjaan sebagai PNS berjumlah 1 orang $(3,2 \%)$, swasta berjumlah 3 orang $(9,7 \%)$, wiraswasta berjumlah 3 orang $(9,7 \%)$, buruh berjumlah 2 orang $(6,5 \%)$, IRT (ibu rumah tangga) berjumlah 21 orang $(67,7 \%)$, pelajar berjumlah 1 orang $(3,2 \%)$.

\section{Diagram 1}

Karakteristik Responden

Berdasarkan Riwayat Pengobatan

Kanker $(\mathbf{n}=31)$

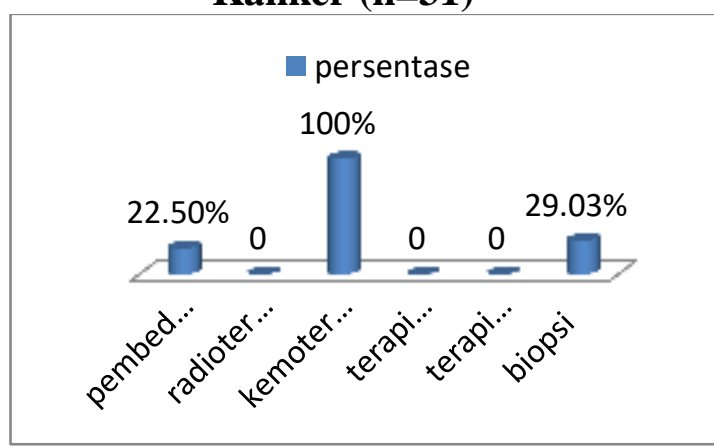

Berdasarkan Diagram 1 menunjukkan bahwa dari 31 responden memiliki riwayat pengobatan pembedahan berjumlah $(22,50 \%)$, riwayat pengobatan dengan kemoterapi berjumlah $(100 \%)$, riwayat pengobatan dengan biopsi berjumlah $(29,03)$.

Tabel 3

Karakteristik Responden Berdasarkan Penyakit Kanker $(n=31)$.

\begin{tabular}{cccc}
\hline Karakteristik & Kategori & N & Presentasi (\%) \\
\hline \multirow{5}{*}{ Jenis kanker } & Ca payudara & 22 & 71,0 \\
\cline { 2 - 4 } & Ca lidah & 3 & 9,7 \\
\cline { 2 - 4 } & Ca colon & 2 & 6,5 \\
\cline { 2 - 4 } & Ca rektum & 1 & 3,2 \\
\cline { 2 - 4 } & Ca parotis & 1 & 3,2 \\
\cline { 2 - 4 } & LMNH & 1 & 3,2 \\
\cline { 2 - 4 } Stadium kanker & KNF & 1 & 3,2 \\
\cline { 2 - 4 } & I & 11 & 35,5 \\
\cline { 2 - 4 } & III & 19 & 61,3 \\
\hline Siklus kemoterapi & IV & 28 & 3,2 \\
\hline
\end{tabular}




\section{Paket B (1-6)}

Berdasarkan Tabel 3 menunjukkan bahwa responden dengan ca payudara berjumlah 22 orang $(71,0 \%)$, ca lidah berjumlah 3 orang $(9,7 \%)$, ca colon berjumlah 2 orang $(6,5 \%)$, ca rektum berjumlah 1 orang $(3,2 \%)$, ca parotis berjumlah 1 orang $(3,2 \%)$, LMNH berjumlah 1 orang $(3,2 \%)$, KNF berjumlah 1 orang $(3,2 \%)$.
3 9,7

Berdasarkan

Tabel

3 menunjukkan bahwa responden dengan kanker stadium I tidak ada, stadium II berjumlah 11 orang $(35,3 \%)$, stadium III berjumlah 19 orang $(61,3 \%)$, stadium IV berjumlah 1 orang $(3,2 \%)$. Berdasarkan Tabel 3 menunjukkan bahwa responden dengan pengobatan kemoterapi berdasarkan dari siklus kemoterapi paket A (1-6) berjumlah 28 orang (90,3\%), dan paket B (1-6) berjumlah 3 orang $(9,7 \%)$.

\section{Pemenuhan Kebutuhan Spiritual}

Tabel 4

Karakteristik Responden Berdasarkan Pemenuhan Kebutuhan Spiritual (n=31)

Pemenuhan kebutuhan spiritual

Frekuensi

Presentasi $(\%)$

\begin{tabular}{lll}
\hline Tidak terpenuhi & 10 & 32,3 \\
\hline Terpenuhi & 21 & 67,7 \\
\hline Total & 31 & 100 \\
\hline
\end{tabular}

Berdasarkan Tabel 4

menunjukkan bahwa sebagian besar responden pasien kanker dengan pemenuhan kebutuhan spiritual

terpenuhi berjumlah 21 orang $(67,7 \%)$, dan yang tidak terpenuhi berjumlah 10 orang $(32,3 \%)$.

Tingkat Kecemasan

Tabel 5

Karakteristik Responden Berdasarkan Tingkat Kecemasan $(n=31)$

\begin{tabular}{lll}
$\begin{array}{l}\text { Tingkat } \\
\text { kecemasan }\end{array}$ & Frekuensi & Presentasi (\%) \\
\hline Ringan & 20 & 64,5 \\
\hline Sedang & 11 & 35,5 \\
\hline Berat & 0 & 0 \\
\hline Panik & 0 & 0 \\
\hline Total & 31 & 100 \\
\hline
\end{tabular}

Berdasarkan Tabel 5 menunjukkan bahwa sebagian besar responden yang memiliki pasien kanker dengan tingkat kecemasan ringan berjumlah 20 orang $(64,5 \%)$, tingkat kecemasan sedang berjumlah 11 orang $(35,5 \%)$, sementara responden yang mengalami tingkat kecemasan berat maupun panik tidak ada.

Analisis hubungan pemenuhan kebutuhan spiritual dengan tingkat kecemasan pada pasien kanker di RSU Kabupaten Tangerang.

Tabel 6

Hubungan Pemenuhan Kebutuhan Spiritual Dengan Tingkat Kecemasan Pada Pasien Kanker 


\begin{tabular}{lccc}
\hline \multirow{2}{*}{ Variabel } & \multicolumn{2}{c}{ Uji Sperman Rho } & \multirow{2}{*}{ Nilai Korelasi (r) } \\
\cline { 2 - 3 } & Mean & SD & \\
\hline Pemenuhan kebutuhan spiritual & 1,68 & 0,475 & \multirow{2}{*}{0.209} \\
\hline Tingkat kecemasan pada pasien kanker & 1,35 & 0,486 & \\
\hline
\end{tabular}

$\mathrm{P}=>0,05(\mathrm{p}=0,258)$

Berdasarkan

Tabel 6

menunjukan bahwa dari hasil uji spearman rho terhadap 31 responden, diperoleh nilai $P=0,258$ maka $P$ value lebih besar dari nilai $\alpha=0,05$ sehingga $\mathrm{H}_{0}$ diterima artinya tidak ada hubungan pemenuhan kebutuhan spiritual dengan tingkat kecemasan pada pasien kanker di RSU Kabupaten Tangerang. Nilai korelasi (r) sebesar -0,209 yang menunjukkan kekuatan korelasi yang sangat lemah dengan arah hubungan yang terjadi bersifat negatif karena nilai (r) negatif sehingga ada kecenderungan bahwa semakin tinggi kebutuhan spiritual maka akan semakin rendah tingkat kecemasannya responden.

\section{PEMBAHASAN}

\section{Pemenuhan Kebutuhan Spiritual}

Hasil analisis univariat mengenai pemenuhan kebutuhan spiritual bahwa sebagian pasien kanker memiliki dengan pemenuhan kebutuhan spiritual terpenuhi berjumlah 21 orang $(67,7 \%)$, dan yang tidak terpenuhi berjumlah 10 orang $(32,3 \%)$.

Menurut Carson (1989) dalam

Achir (2008) Kebutuhan spiritual adalah kebutuhan untuk mempertahankan atau mengembalikan keyakinan dan memenuhi kewajiban agama, mencintai, menjalin hubungan penuh rasa percaya dengan Tuhan.

Pada pasien kanker, terutama kanker stadium lanjut, upaya penyembuhan menjadi sangat sulit, sedikit sekali pasien yang dapat kembali pulih dari penyakitnya (Nuraeni dkk, 2015). Pasien dengan kondisi terminal seperti ini, hal yang dianggap sangat berharga adalah spiritual (Nuraeni dkk, 2015).
Dalam penelitian ini diketahui rata-rata usia responden 45,94 tahun dengan nilai termuda 17 tahun dan usia tertua 64 tahun. Usia perkembangan dapat menentukan proses pemenuhan kebutuhan spiritual, karena setiap tahap perkembangan memiliki cara meyakini kepercayaan terhadap tuhan (Hidayat dan Uliyah, 2016). Di mana dalam usia produktif ini lebih matang dalam pengetahuannya mengenai agama, sehingga lebih mudah untuk diberikan arahan mengenai spiritualnya.

\section{Tingkat Kecemasan Pada Pasien Kanker}

Terdapat empat tingkat kecemasan, yaitu: ringan, sedang, berat, panik (Maryam dkk, 2008). Hasil analisis univariat mengenai tingkat kecemasan pada pasien kanker, didapatkan hasil yang mengalami tingkat kecemasan ringan sebanyak 20 orang (64,5\%), tingkat kecemasan sedang sebanyak 11 orang $(35,5 \%)$, tingkat kecemasan berat tidak ada, tingkat kecemasan panik tidak ada.

Hal ini sejalan dengan penelitian Rahmawati dkk (2015) dengan judul mekanisme koping berhubungan dengan tingkat kecemasan pasien kemoterapi di ruang kemoterapi RS Urip Somoharjo Lampung hasil uji statistik diperoleh nilai p-value sebesar 0,004 (lebih kecil dari nilai alpha $=0,05)$ dari 90 responden tidak memiliki kecemasan yaitu 7 orang $(7,8 \%)$ memiliki tingkat kecemasan ringan yaitu 53 orang $(58,9 \%)$, tingkat kecemasan sedang 27 orang $(30,0 \%)$, tingkat kecemasan berat 3 orang $(3,3 \%)$.

Lutfa \& Arina (2008) dalam Utami dkk (2013) menunjukkan korelasi usia dengan kecemasan 
memberi pengaruh sebesar 35\%, korelasi pendidikan pasien dengan kecemasan memberi pengaruh sebesar $32 \%$; Korelasi tingkat adaptasi dengan kecemasan memberi pengaruh sebesar 46\% terhadap kecenderungan menurunnya kecemasan pasien dalam menjalani kemoterapi. Hasil analisa menunjukkan faktor usia, pendidikan, pengalaman tidak mempengaruhi kecemasan pasien dalam tindakan kemoterapi, sedangkan adaptasi mempengaruhi tingkat kecemasan pasien kemoterapi (Utami dkk, 2013).

\section{Hubungan pemenuhan kebutuhan spiritual dengan tingkat kecemasan pada pasien kanker}

Berdasarkan Tabel 6 menunjukan bahwa dari hasil uji spearman rho terhadap 31 responden, diperoleh nilai $P=0,258$ maka $P$ value lebih besar dari nilai $\alpha=0,05$ sehingga $\mathrm{H}_{0}$ diterima artinya tidak ada hubungan pemenuhan kebutuhan spiritual dengan tingkat kecemasan pada pasien kanker di RSU Kabupaten Tangerang. Nilai korelasi (r) sebesar -0,209 yang menunjukkan kekuatan korelasi yang sangat lemah dengan arah hubungan yang terjadi bersifat negatif karena nilai (r) negatif sehingga ada kecenderungan bahwa semakin tinggi kebutuhan spiritual maka akan semakin rendah tingkat kecemasannya responden.

Pasien merasakan pentingnya pemenuhan kebutuhan spiritual (Nuraeni dkk, 2015). Pada pasien kanker, terutama kanker stadium lanjut, upaya penyembuhan menjadi sangat sulit, sedikit sekali pasien yang dapat kembali pulih dari penyakitnya (Nuraeni dkk, 2015). Pasien dengan kondisi terminal seperti ini, hal yang dianggap sangat berharga adalah spiritual (Nuraeni dkk, 2015).

Menurut Nuraeni (2015) Penelitian deskriptif kuantitatif ini melibatkan 76 pasien kanker yang sedang menjalani perawatan di salah satu RS di Bandung yang diambil dengan accidental sampling. Hasil penelitian menunjukkan bahwa pada aspek religi, berdoa dengan orang lain dan seseorang berdoa untuk responden memiliki persentase paling tinggi $(96,05 \%)$. Pada aspek kedamaian, tinggal di tempat yang tenang dan damai serta menemukan kedamaian batin memiliki persentase paling tinggi (89,47\%). Pada aspek eksistensi diri, menemukan makna dalam sakit dan penderitaan memiliki persentase paling tinggi $(94,74 \%)$. Adapun pada kebutuhan untuk memberi, beralih menjadi orang yang penuh cinta kasih memiliki persentase paling tinggi $(89,47 \%)$.

Walaupun kebutuhan spiritual pada pasien kanker sangat di butuhkan tetapi dalam penelitian ini menunjukan tidak ada hubungan antara pemenuhan kebutuhan spiritual dengan tingkat kecemasan pasien kanker. Di karenakan tingkat kecemasan pada pasien kanker disini cenderung ringan. Dikarenakan pasien yang menjalani kemoterapi sudah bisa beradaptasi dengan kemoterapi itu sendiri sehingga tingkat kecemasanpun cenderung rendah (Utami dkk, 2013).

Menurut Lutfa \& Arina (2008) dalam Utami dkk (2013) menunjukkan korelasi usia dengan kecemasan memberi pengaruh sebesar 35\%, korelasi pendidikan pasien dengan kecemasan memberi pengaruh sebesar $32 \%$; Korelasi tingkat adaptasi dengan kecemasan memberi pengaruh sebesar 46\% terhadap kecenderungan menurunnya kecemasan pasien dalam menjalani kemoterapi.

\section{KESIMPULAN}

1. Pemenuhan kebutuhan spiritual pada pasien kanker di RSU Kabupaten Tangerang terdapat 
pemenuhan kebutuhan spiritual yang tidak terpenuhi sebanyak 10 responden $(32,3 \%)$ dan yang terpenuhi sebanyak 21 orang $(67,7 \%)$.

2. Tingkat kecemasan pada pasien kanker di RSU Kabupaten Tangerang terdapat 20 orang $(64,5 \%)$ responden mengalami tingkat kecemasan ringan, 11 orang $(35,5 \%)$ responden mengalami tingkat kecemasan sedang, responden yang mengalami tingkat kecemasan berat dan panik tidak ada.

3. Tidak ada hubungan pemenuhan kebutuhan spiritual dengan tingkat kecemasan pada pasien kanker di RSU Kabupaten Tangerang. dapat dilihat bahwa dari hasil uji spearman rho terhadap 31 responden, diperoleh nilai $P=$ 0,258 maka $P$ value lebih besar dari nilai $\alpha=0,05$ sehingga $\mathrm{H}_{0}$ diterima artinya tidak ada hubungan pemenuhan kebutuhan spiritual dengan tingkat kecemasan pada pasien kanker di RSU Kabupaten Tangerang. Nilai korelasi (r) sebesar -0,209 yang menunjukkan kekuatan korelasi yang sangat lemah dengan arah hubungan yang terjadi bersifat negatif karena nilai (r) negatif sehingga ada kecenderungan bahwa semakin tinggi kebutuhan spiritual maka akan semakin rendah tingkat kecemasannya responden.

\section{SARAN}

1. Bagi rumah sakit

Walaupun sebagian pasien memiliki tingkat kecemasan kategori ringan tetapi ada beberapa yang memiliki tingkat kecemasan kategori sedang, di harapkan pihak rumah sakit dapat lebih memperhatikan kebutuhan spiritual pasien.

2. Bagi instasi kesehatan
Di harapkan tenaga medis mampu memberikan dan memenuhi kebutuhan baik di care maupun di bagian spiritual.

3. Bagi pasien

Di harapkan pasien merasa lebih termotivasi dalam beribadah walaupun sedang sakit, pasien merasa terdorong dan terbantu dalam pribadahnya.

4. Bagi peneliti selanjutnya

Diharapkan peneliti selanjutnya dapat meneliti lebih lanjut berdasarkan faktor lainnya yang menyebabkan kurang terpenuhinya kebutuhan spiritual di rumah sakit lain, jumlah sampel yang lebih banyak, desain yang lebih tepat dan tetap berhubungan dengan perawatan paliatif dan jiwa.

\section{DAFTAR PUSTAKA}

Abuatiq, Alham. 2015. Spiritual Care for Critical Care Patients. International Journal of Nursing \& Clinical Practices. http://dx.doi.org/10.15344/2394$\underline{4978 / 2015 / 128}$.

Achir, Yani.S.H. 2008. Bunga Rampai Asuhan Keperawatan Kesehatan Jiwa. Jakarta: EGC.

Ariyani, Hana dkk. 2014. Persepsi perawat dan pasien sindroma koroner akut terhadap kebutuhan spiritual. Jurnal Kesehatan Komunitas Indonesia Vol. 10. No. 1 Maret 2014.

Hidayat. A. Aziz Alimul dan Uliyah, Musrifatul. 2016. Buku Ajar Ilmu Keperawatan Dasar. Jakarta: Salemba Medika.

http://www.depkes.go.id/article/view/17 020200002/kementeriankesehatan-ajak-masyarakatcegah-dan-kendalikan- 
kanker.html\#sthash.vr5zYbCW. dpuf. Di Publikasikan Pada: Kamis, 02 Februari 2017.

Kementrian Kesehatan RI. 2015. Pusat Data dan Informasi. Jakarta Selatan.

http://www.depkes.go.id/resourc es/download/pusdatin/infodatin/i nfodatin-kanker.pdf

Lubis, N. dan Hasimin, M. 2009. Dampak Intervensi kelompok kognitif behavioral therapy dan kelompok dukungan sosial dan sikap menghargai diri sendiri pada kalangan penderita kanker payudara. Skripsi. Fakultas Kesehatan Masyarakat Universitas Sumatra Utara.

Maryam, R. Siti dkk. 2008. Mengenal Usia Lanjut dan Perawatannya. Jakarta: Salemba Medika.

Nuraeni, Aan dkk. 2015. Kebutuhan Spiritual pada Pasien Kanker. Fakultas Keperawatan Universitas Padjadjaran.

Nurpeni, Ratih Khrisna Made dkk. 2013. Hubungan Dukungan Keluarga Dengan Tingkat Kecemasan Pada Pasien Kanker Payudara (Ca Mamae) Di Ruang Asoka III RSUP Sanglah Denpasar. Program Studi Ilmu Keperawatan Fakultas Kedokteran Universitas Udayana.

Rahmah, Andi. 2016. Kecemasan Pasien dan Dukungan Keluarga pada Penderita Kanker Serviks. ejournal.psikologi.fisipunmul.ac.id
Subagja, Hamid Prasetya. 2014. Waspada!!! Kanker-kanker Ganas Pembunuh Wanita. Jogjakarta: FlashBooks.

Utami, Dewi dkk. 2013. Hubungan Dukungan Keluarga Terhadap Tingkat Kecemasan Kemoterapi Pada Pasien Kanker Serviks Di RSUD Dr. Moewardi. STIKes Aisyiyah Surakarta. 